DOI: $10.4274 /$ tpa. 848

\title{
Sexual abuse and incest
}

\author{
Figen Şahin1, Medine Ayşin Taşar2 \\ 1 Gazi University, Medical Faculty, Department of Pediatrics, Division of Social Pediatrics, Ankara, Turkey \\ 2S.B. Ankara Education and Research Hospital, Ankara, Turkey
}

\section{Summary}

Incest, which is the severest form of child sexual abuse is defined as the sexual behaviours between close relatives whose marriage is illegal or describes inappropriate sexual behaviours within a family relation framework. Incestous relation is accepted as a taboo, therefore it is frequently a secret within the family and is a chronic process which is hard to recognize. It is important to recognize and prevent incest because it is more difficult to be revealed compared to other forms of abuse and results in severe and long term consequences in victims. Physical, emotional and social consequences of incest are very severe and last for a lifetime. Prevention of incest is closely linked to prevention of child sexual abuse. Collaboration of different parts of child protection system, namely, healthcare system, social services, law enforcement and legal systems; and a well structured education of the professionels working in the field as well as sensitive media which helps awareness raising about child sexual abuse may be effective means of prevention. (Turk Arch Ped 2012; 47: 157-162)

Key words: Child, sexual abuse, incest

\section{Introduction}

Child sexual abuse (sexual misuse) is involvement of the child in sexual activities which he/she can not comprehend, for which he/she is not ready developmentally, which he/she would not give approval and which are contradictory to regulations and the community's cultural values by an adult or a child who is chronologically or developmentally older than himsel/herself for the aim of satisfying the opponent's sexual desire (1). This abuse can be oral-genital, genital-genital, genital-rectal, handgenital, hand-rectal and hand-breast or can be in different ways including exhibiting genital organs, forcing the child to exhibit his/her genital organs, showing the child porgonraphic content or using the child in pornography $(1,2)$. Sexual abuse which has been proven to harm the child in any way leads to more serious problems if it is performed by individuals whom the child trusts the most. This situation which is called incest can be defined as sexual relation between two individuals who are legally prohibited to get merried and describes inappropriate sexual behaviour in the framework of familial relationship. It may occur with the mother or the father, a close relative or someone who has undertaken the role of a parent including the stepfather (2).
Incest relationship is usually accepted as a taboo in the community, it is kept hidden and is a chronic event. It's diagnosis and follow-up is difficult $(1,2)$. Incest is more important compared to other abuse types because of two reasons. The first one is the fact that experience of sexual abuse in the family makes it difficult to be revealed because of its unacceptibility by the community and fear that the family will break $(3,4,5)$. The second one is the fact that more severe and long-term damage occurs in victims compared to the other types (5).

\section{History}

Although sexual abuse is as old as the human history, its revealment and its becoming talkable have occured only in very recent times. In the second half of the $19^{\text {th }}$ century, French doctors Tardieu, Bernard and Brouardel tried to bring this issue to agenda, but they were not successful. In the $20^{\text {th }}$ century, Sigmund Freud tried to remove the blanket on sexual abuse, but later stated that sexual abuse of children by adults was an unreal event which developed as a result of imagination and fantasy of children (3). It's being an unreal event was accepted 
more readily. With the activities of woman groups attention of the community and experts was drawn to sexual abuse in the years of 1960-70 and studies started (3). After Kempe (1) reported sexual abuse as "a hidden child issue" in 1977 awareness on this issue increased in the whole world.

\section{Frequency}

The frequency of sexual abuse and especially incest is not known exactly, since it is kept hidden. In a study performed, it was estimated that $1 \%$ of children were exposed to sexual abuse each year and as a result of this $8-10 \%$ of boys and $12-$ $25 \%$ of girls were exposed to sexual abuse by the age of 18 years (6). In Canada, it has been reported that more than 1,5 million women are exposed to sexual abuse, 545 new cases are added each year and female/male ratio is $2.5(3,5)$. In a study performed in high-school students, it was found that $10.8 \%$ of girls and $4.2 \%$ of boys were exposed to sexual abuse (7). In a study performed in 9684 adults in USA, $10.6 \%$ of women and $2.1 \%$ of men reported that they had been exposed to sexual abuse. $60.4 \%$ of these women and $69.2 \%$ of these men were exposed to sexual abuse before the age of 18 years and $25,5 \%$ of the women and $41 \%$ of the men were exposed to sexual abuse before the age of 12 years. $30.4 \%$ of the women stated that they had been abused by their partners, $23.7 \%$ stated that hey had been abused by family members, $20 \%$ stated that they had been abused by acquaintances. $32.3 \%$ of the men reported that they had been abused by acquaintances, $17.7 \%$ reported that they had been abused by family members and $17.6 \%$ reported that they had been abused by friends (8). In a meta-analysis, sexual abuse was found with a rate of $7.9 \%$ in boys and $19.7 \%$ in girls. When evaluated by regions the frequency of sexual abuse is highest in Africa region with a rate of $34 \%$. It has been reported to be $10 \%$ and $24 \%$ in America, Asia and Ocean region and 9\% in Europe (9). According to a research performed by the World Health Organization the prevalence of sexual abuse is $10-20 \%$ and $43 \%$ of these cases include abuse by family members (10).

In a study performed in our country which investigated violence agains women, it was found that $7 \%$ of women had been exposed to sexual abuse before the age of 15 years and this rate was 3 fold higher in urban areas compared to rural areas and $30 \%$ of the exploiters were male relatives (11). In a study performed in 1955 high-school students in Turkey, 13.4\% of the students were reported to be exposed to sexual abuse and $1.8 \%$ of this were reported to be incest cases (12). In another study performed in our country, the rate of incest was reported to be $1.4 \%$ (13).

In sexual abuse cases, it is known that the child is abused especially by individuals who he/she knows. In intrafamily abuse, the exploiter is mostly the father and the most common relationship is reported between the father and the daughter. Although the stepfather has been reported to be the exploiter with a 5 fold higher rate compared to the biological father in foreign publications, $57 \%$ of the exploiters were found to be biological fathers and $7 \%$ were found to be stepfathers in a study performed in Turkey in which incest cases were examined $(1,14)$. In another foreign study, $39 \%$ of the exploiters were reported to be biological fathers and $23 \%$ were reported to be stepfathers (15).

\section{Incest types}

In incest cases, fathers and substitutes of fathers comprise the largest exploiter group. Sister-brother, mother-son, grandmother or grandfather-grandchild are other rare incest types.

"Emotional incest" defined as sexualization of the relationship between the parents and the child is an incest type which was started to be discussed after 1980s. In this type, there is no body contact. It may include showing pornographic tools, exhibition of sexuality, sexual statements or making fun of the child's genital organs. This type has been reported to be related to moving away of the mother and the father from each other emotionally and sexually because of the problems between them. Its negative effects on the child is similar to the other incest types (16).

\section{The characteristics of incest abuse and its effects on the child}

Most of the exploiters are defined as "normal" people. Adult exploiters show different economic, psychological and demographic properties. Most of them have a succesful career and have no previous criminal report (5). It has been reported that incest criminals are more intraverted, passive and dependent compared to other sexual exploiters, have no empathy, have more repetitive thoughts and have been given less care by their parents $(16,17)$.

The most common exploiter is the father in incest cases. The father's sexual desires, the girl's need for love and desire to continue family life when the mother works or has an organic or mental illness may predispose to this kind of relationship (5). The fathers are usually defined as rough, patriatchal and emotionally unstable individuals. In incest relationships, it has been reported that the fathers had not been in the house in the first years of their children whom they abuse, did not cared for these children and as a result no emotional identification was established between the father and the child (16). In this type of incest, the exploiter may have three types of psychiatric disorder: 1- Endogamic (intragroup marriage): These fathers limit their sexual relations with family members. They do not wish to have sexual or social relationship with other women outside the family. 2- The ones who have random sexual relationship. These fathers are usually psychopaths. 3- The ones who find children sexually attractive (pedophilia): These fathers have delayed psychosexual development and are socially immature (18). 
Most victims are girls. It is thought that boys are exposed to sexual abuse as frequently as girls, but notice is less frequent (1). Individuals with mental retardation are exposed to sexual abuse 4-10 times more frequently compared to the general population $(1,19)$. The reasons that these individuals are exposed to sexual abuse with a high rate include trust in the authority figure who is the caregiver, fear, social and emotional distrust and lack of knowledge about sexuality and sexual abuse.

Incest is found in many cultures and at all socioeconomic levels in contrast to other types of abuse (1). In a study performed in Turkey in which forensic case files were examined, $94 \%$ of the exploiters were found to be uneducated or primary school graduates and $50 \%$ were found to be unemployed. It is thought the reason for this is that incest can be kept hidden more easily in families with high socioeconomic level (14). In another study performed in Turkey, incest resulted in "penetration" with a higher rate in villages and small towns compared to cities and was reported to legal authorities approximately 10 days later (20). Factors which affect the frequency of incest include alcohol and substance misuse, crowded family, increased physical intimacy, divorce and exclusion of the family from the community (Table 1) $(1,6,16)$.

Definition of incest medically is difficult especially in adolescents and adults because of abscence of specific findings. In younger children, it can be recognized especially by the family physician with some findings (21). In addition, the family and/or the child may refer to healthcare institutions frequently because of unimportant and recurrent problems. Certain signs and symptoms warn physicians (Table 2) $(5,21)$. The diagnosis is made by history. Physical examination and laboratory findings are rarely helpful.

The factors which affect the degree of harm arising from sexual abuse are shown in Table $3(5,22)$. The victim may question the situation immediately after the event and it is possible to decrease the psychological harms if management is done well (3).

Child sexual abuse is a case framed by suspicions, denial, disbelief, disgust and uncertainity. Children may hide abuse, since they are afraid of the reactions of adults and think that they will not be believed and trusted. The most important determinants of the reactions of adults and the children's fears are the community's judgements and values (16).

Other reasons for nonresistance of incest victims include fear of physical violence, lack of knowledge, feelings for the exploiter, threat to the family, weakness, expectation that the mother will reveal the event and the strong position of the exploiter (16).

The possibility that incest relationship is recurrent and is an event lasting for long years is high; it has been reported to be recurrent with a rate of $58 \%$ (14). In chronic incest cases, the child is in trouble and weak. Most children accuse themselves and think that they are bad.
In incest, the exploiter is the source of both security and danger. Sexual trauma originating from the family which is thought to be the most safe environment for the child is expected to result in more serious outcomes compared to external sexual abuse $(16,23)$.

\section{Table 1. Risk factors for incest}

Alcoholic father

Psychiatric disorders in family members

Presence of incest relation in the family of the father and/or the mother

Impotence, psychopathology

A mother who is ill or a mother who has left home

Care of children by the father or stepfather because the mother has to work in the night

Sharing of the same room and bed by adults and children

Girls living seperate form their fathers

Being a girl of 6-8 years of age

Table 2. Signs and symptoms which suggest sexual abuse

Trauma in the genital region

Presence of sexually transmitted diseases

Chronic vulvovaginitis

Abnormal findings on genital examination

Pregnancy

Emotional disorders

Sexual behaviour inappropriate for age and development and sexual plays

Table 3. Factors which affect the degree of harm caused by sexual abuse

Age and development state of the victim

Psychological status of the victim before the event

Frequency of abuse

Period of abuse

Painful experience

Vaginal or anal penetration

Physical forcing or threat

Intimate relation between the victim and the exploiter

Support to the victim by the family

Management of the case 
In incest, the most common findings in the short-term include fear and axiety. Regression of abilities, agression, abscence from school, decrease in academic success, urinary-fecal incontinence, headache-abdominal pain, finger sucking, nail-biting and sleep disorders may be observed. In older children, depression, feeling of guilty, tendency to crime and sexual relation with different people may be observed $(2,22)$. The victims grow up being aware that they are different from other children and people around them and carry a disgrace and a shameful secret. As a result of this it is inevitable that embarrassment, feeling of being deceived, alienation, anger and irritation occur (16).

Emotional disorders due to incest relationship become visible beginning from the start of adolescence. The most common psychological disorder in the long-term is "posttraumatic stress disorder" which include thoughts of guilty, low self-esteem, weakness, learned helplessness and suicide. However, split personalty is also a frequently observed finding (Table 4) $(5,16)$. In a meta-analysis, sexual problems have been found in $28 \%$ of individuals who were exposed to sexual abuse (24). In addition, sexual abuse was found with a rate of $48 \%$ in children who showed inappropriate, agressive and compulsory sexual behaviour (25). It has been reported that $50 \%$ of prostitutes experience their first sexual relation with their fathers (14).

When victims can not understand that they did not cause the event or it was not their fault, they internalize the feeling of guilty and psychological problems arise. Revealance of the event and explaining the victim that this was not his/her fault, he/she did not deserve this and he/she is not alone in this process lead to a decrease in the psychological effects. In addition, it is important to develop intrafamily communication and relations with the other parent as well as individual therapy $(1,6)$. The factors which affect the success of treatment include personality characteristics of the victim, his/her commitment for getting help, rapid, supportive, reliable, problem-focused, multi-diciplinary approach of the treatment

\section{Table 4. Long-term effects of sexual abuse experienced in} the childhood

\begin{tabular}{|l|l|}
\hline Anxiety disorder & Sexual dysfunction \\
\hline Phobias & Somatization \\
\hline Substance abuse & Posttraumatic stress disorder \\
\hline Psychosis & Anorexia nervosa \\
\hline Tendency to suicide & Split personality \\
\hline $\begin{array}{l}\text { Being against to establish a family } \\
\text { and being against sexuality }\end{array}$ & Borderline personality disorder \\
\hline Weak impulse control & Abusing his/her own child \\
\hline & Confidence problems \\
\hline
\end{tabular}

team, keeping judgements and values related to cultural pressure away from treatment environment and collobaration of social supports $(1,16,26)$.

Incest is an experience which should be evaluated with its social dimension and in which all family members and intrafamily dynamics should be reviewed (6). Revealance of the illegal relationship to the community and labeling of the family in this way lead damage in social network. Thus, such a labeling of individuals and a bad reputation in the social environment cause the victim to perceive himself/herself as an unvaluable person. Exclusionist attitude of people leads to a feeling of social distance, loneliness and in the end depression and suicide. On the other hand, these individuals may display deviated behaviour in order to stand on their feet inside the community and to acquire an identity and even may be forced to crime or be a target of crime organizations. In this way, they accept to work in the worst working conditions in the community and in occupations with no or low respectfullness; they become marginalized $(16,18)$.

\section{Approach in incest}

Children may be forced to neglect or hide incest by the family and the community to protect the structure of the family. In addition, the child may disclaim accusation with fear of being mocked, mistrusted, being accused and being excluded by relatives and friends (lack of fullfilment of their needs and lack of love) (2). The possibility of breaking of the family, revealance of the event to friends in the school and to the family environment and talking about "being dishonored" leads the event to be kept hidden. In addition, the concern that the individual whom the family needs economically or socially will be punished and thus the life of the family will be difficult inhibits revealance of incest $(6,16)$. Even the experts who work in the child protection system sometimes think that revealance of the event would be harmful for the child rather than beneficial and may experience a dillemna in terms of notice (4).

The individuals who deal with sexual abuse cases may experience difficulty in controlling their feelings and thoughts about the exploiter. It is important not to be biased and to make evaluations as experts while resolving the event. Psychological evaluation of the exploiters may reveal personality disorder, alcohol and substance use and exposure to sexual abuse in the childhood and they may have a chance for treatment when evaluated in these aspects $(16,26)$. Although some experts report that the expoiters are guilty and should be punished, some others report that they are ill, punishment is not a right approach and they should be treated $(3,6)$. Drug treatment, cognitive, behaviorial and family directed treatment methods are being used in treatment of incest criminals. In drug treatment, drugs which decrease sexual impulse are administered especially to individuals who can not control their sexual behaviour and who constitute a risk for the community. 
Family directed treatments are used in cases where abuse is not continuing and the child is protected from abuse (16).

In these cases, multidiciplinary approach performing assessment in terms of medical, social and legal aspects is needed. In this way, the child and the family is protected from recurrent interviews and examinations and handled in an experienced and child-friendly environment. It is possible that the child is harmed severly because of problems confronted in various stages of the diagnostic process and afterwards. Lack of knowledge or adequate sensitivity of the individuals working in the Child Protection system leads to a secondary abuse for the child. With Law of Criminal Procedure arrangements were made to prevent child victims from being agrieved by the sysem for the second time. These arrangements include free assigment of a lawyer, interrogation only for once unless mandatory and providing an expert during testimony.

The $103^{\text {rd }}$ article of the Turkish Criminal Law defines sexual abuse committed against children (27). According to this article sexual abuse committed against children is defined as "any sexual behaviour committed against children who have not completed 15 years of age or who has not yet developed the ability to perceive the legal meaning and results of the act though he/she has completed 15 years of age" and "sexual behaviour committed agains other children based on only violence, threat, trick or another factor affecting the willpower" and is punished with prison sentence from 3 years to 8 years. If sexual abuse is committed by lineal relatives, second or third-degree relatives, stepfather, adoptive parents, guardian, educator, teacher, caretaker, healthcare provider or other people who have the responsibility of protection and supervision or by the way of using the potency provided by service relation, the punishment to be given according to the above-mentioned articles is increased by half. This is important in terms of emphasizing that incest is viewed as a more heavier crime compared to other sexual abuse cases also in our regulations.

Notices should be made to legal authorities to determine and punish individuals who neglect and abuse children. Physical and sexual abuse cases occuring between family members are not reported to legal authorities in order to protect the family. Only the child is treated and the exploiters are not being punished. As a result of this abuse continues and the child can not be protected. In the 278th and 279th articles of the Turkish Criminal Law, punisments for individuals who do not notice abuse are arranged. The 280th article of the Turkish Criminal Law states: "If a healthcare worker confronted with any sign of crime while performing his/her task does not report the situation to legal authorities or delays to report the situation, he/she is punished with a prison sentence up to one year."

In a field study performed by Population Science Association in 2009 named " to understand the problem of incest in Turkey", four basic points were determined to develop a solution for the problem of incest in Turkey (28). These included education of counsellors, increasing the awareness of law employees, performance of psycological evaluation by experts on the field and establishing multidiciplinary centers in health institutions where pediatricians, pediatric psychiatrists, specialists of forensic medicine and social service experts work together.

Incest is one of the problems which has the most serious physical, psychological and social outcomes and its effects continue for a life time. Prevention of incest is predominantly dependent on prevention of child sexual abuse. In this aspect, collaboration of healthcare and social service systems, law enforcement officers and justice system, informative and didactic publications of written and visual media with a responsible and sensitive approach, organization of pre- and post-graduate trainings of individuals who work on the field in a strong way may be beneficial to prevent incest. Intensive sociological activities are needed to correct value judgements about sexuality in the community and to transform the repressive society structure where the victim of sexual abuse is dishonoured and sexuality is disgraceful and prohibited to a structure where sexual education is given and sexuality is experienced in appropriate and safe ways.

\section{References}

1. Kellogg N, American Academy of Pediatrics Committee on Child Abuse and Neglect. The evaluation of sexual abuse in children. Pediatrics 2005; 116(2): 506-512.

2. Johnson CF. Abuse and neglect of children. In: Behrman RE, (ed). Nelson textbook of pediatrics. 18th ed. Philadephia: Saunders, 2008: 178-182.

3. Finkel M, Dejong AR. Medical findings in sexual abuse. In: Reece RM, (ed). Child abuse: diagnosis and treatment. 2nd ed. New York: Lippincott, Williams \& Wilkins; 2001: 207-286.

4. Şahin F, Beyazova U. Çocuğun cinsel istismarında adli bildirim. Hekimin ikilemi. Adli Tıp Dergisi 2003; 17(2): 47-51.

5. Finkel KC. Sexual abuse and incest. What can you do? Can Fam Physician 1994; 40: 935-944.

6. Finkelhor D. Current information on the scope and nature of child sexual abuse. Future Child 1994; 4(2): 31-53.

7. Centers for Disease Control and Prevention. Youth risk behavior surveillance-United States, 2005. Surveillance summaries. MMWR 2006; 55: 1-5.

8. Basile KC, Chen J, Black MC, Saltzman LE. Prevalence and characteristics of sexual violence victimization among U.S. adults, 2001-2003. Violence Vict 2007; 22(4): 437-448.

9. Pereda N, Guilera G, Forns M, Gómez-Benito J. The international epidemiology of child sexual abuse: a continuation of Finkelhor (1994). Child Abuse Negl 2009; 33(6): 331-342.

10. World report on violence and health, 2002. Dünya Sağlık Örgütü. www. who.int/violence_injury_preventation. Erişim tarihi: Ekim, 2010.

11. Başbakanlık Kadının Statüsü Genel Müdürlüğg̈: Türkiye'de kadına yönelik aile içi şiddet, Ankara, 2009. http://www.ksgm.gov.tr/tdvaw. Erişim tarihi: Ekim, 2010.

12. Alikasifoglu M, Erginoz E, Ercan O, Albayrak-Kaymak D, Uysal O, Iter O. Sexual abuse among female high school students in Istanbul, Turkey. Child Abuse Negl 2006; 30(3): 247-255.

13. Koten $Y$. Üniversite öğrencilerinde cinsel tutum ve davranışlar ile sosyoekonomik durum ve psikiyatrik semptom dağılımının karşılaştıııması. Trakya Üniversitesi Tıp Fakültesi Psikiyatri Anabilim Dalı Tıpta Uzmanlık Tezi, Edirne, 1996.

14. Öztürk M, Güzelhan Y, Ortaköylü L. Ensest öyküsü olan adli olguların incelenmesi. Yeni Sempozyum 2000; 38(1): 15-18. 
15. Peirce RL, Peirce LH. Analysis of sexual abuse hotline reports. Child Abuse Negl 1985; 9(1): 37-45.

16. Topçu S. Ensest. İçinde: Özçelik B (yazar). Cinsel İstismar. Ankara: Phoenix, 2009: 81-124.

17. Lu YC, Lung FW. Perceived parental attachment, personality characteristics, and cognition in male incest. Int J Offender Ther Comp Crimino 2012; 56(4): 557-572.

18. Baran Görgün A, Erbaydar Paksoy N. Yasak cinsel ilişki: ensest. http://www.huksam.hacettepe.edu.tr. Erişim tarihi: Eylül, 2010.

19. Pincus S. Sexuality in the mentally retarded patient. Am Fam Physician 1988; 32(2): 319-323.

20. Gunduz T, Karbeyaz K, Ayranci U. Evaluation of the adjudicated incest cases in Turkey: difficulties in notification of incestuous relationships. $J$ Forensic Sci 2011; 56(2): 438-443.

21. Johnson MS. Recognizing the incestuous family. J Nati Med Assoc 1983; 75(8): 757-761.

22. Ovayolu N, Uçan Ö, Serindağ S. Çocuklarda cinsel istismar ve etkileri. Fırat Sağlık Hizmetleri Dergisi 2007; 2(4): 13-22.
23. Gültekin G, Ruban C, Akduman B, Korkusuz i. Çocuk ve cinsel istismar. Adli Psikiyatri Dergisi 2006; 3(1): 9-14.

24. Kendall-Tackett KA, Williams LM, Finkelhor D. Impact of sexual abuse on children: a review and synthesis of recent empirical studies. Psychol Bull 1993; 113(1): 164-180.

25. Kellogg ND; Committee on Child Abuse and Neglect, American Academy of Pediatrics. Clinical report-the evaluation of sexual behaviors in children. Pediatrics 2009; 124(3): 992-998.

26. Devrimci Özgüven H, Soykan Ç, Yazar H. Bir yasak-sevi olgusuna yaklaşım ve karşılaşılan güçlükler. Türk Psikiyatri Dergisi 2003; 14(4): 311-318.

27. Türk Ceza Kanunu. http://www.tbmm.gov.tr/kanunlar. Erişim tarihi: Kasım, 2010.

28. Bozbeyoğlu- Çavlin A, Nüfusbilim Derneği ve Birleşmiş Milletler Nüfus Fonu. Türkiye'de ensest sorununu anlamak, Ankara, 2009. http://www.unfpa.org.tr/turkeytr. Erişim tarihi: Ekim, 2010. 